\title{
SISTEM PEMESANAN TIKET PADA JOGLOSEMAR EXECUTIVE SHUTTLE BUS SEMARANG
}

\author{
Perawaty Panjaitan ${ }^{1)}$, Nurdin Bahtiar²), Sukmawati Nur Endah ${ }^{2)}$ \\ Alumni Program Studi Matematika ${ }^{1)}$, Program Studi Teknik Informatika ${ }^{2)}$ \\ Jurusan Matematika FMIPA UNDIP \\ sukma_ne@undip.ac.id
}

\begin{abstract}
Abstrak
Pengelolaan data pada Joglosemar Executive Shuttle Bus Semarang mengalami beberapa permasalahan seperti penginputan data yang tidak efektif dan efisien, sulit dalam pencarian data sesuai informasi yang diperlukan, sulit dalam memberikan informasi dengan cepat kepada calon pembeli tiket dan penyimpanan laporan data-data pemesanan tiket yang tidak terorganisir dengan baik. Permasalahan itu disebabkan karena pengelolaan data pemesanan tiket masih bersifat manual atau belum terkomputerisasi. Untuk menangani permasalahan tersebut maka dibuat sistem pemesanan tiket berbasis desktop dengan menggunakan metode pengembangan sistem sekuensial linier. Perangkat lunak yang digunakan untuk pengembangan program antarmuka adalah Microsoft Visual Basic 6.0 dan perangkat lunak yang digunakan untuk media penyimpanan data adalah Microsoft Access 2007. Berdasarkan hasil pengujian didapatkan bahwa sistem pemesanan tiket berjalan dengan baik sehingga dengan adanya sistem pemesanan tiket ini dapat memberi kemudahan dalam pengelolaan data pemesanan tiket.
\end{abstract}

Kata kunci : Sistem, Pemesanan Tiket, Joglosemar Executive Shuttle Bus

\section{Pendahuluan}

Transportasi adalah salah satu kebutuhan vital bagi masyarakat, baik transportasi udara, darat maupun laut. Transportasi darat di Indonesia merupakan sarana paling penting dalam memajukan perekonomian nasional. Dalam era globalisasi yang cepat ini dibutuhkan suatu transportasi yang cepat, nyaman dan aman [1]. Banyak orang memilih bus eksekutif untuk perjalanan karena cepat, nyaman dan aman. Sebelum melakukan perjalanan calon penumpang bus eksekutif harus terlebih dahulu memesan tiket ke agen mengenai kemana tempat yang akan dituju dan kapan jadwal keberangkatannya. Saat ini banyak agen yang mengolah data pemesanan tiket bus eksekutif masih secara manual, salah satunya agen untuk bus eksekutif joglosemar yang bertempat di Banyumanik sebagai lokasi penelitian.

Informasi yang terkoordinir mempunyai pengaruh penting yaitu manajer dapat memantau kondisi manajemen bus agar dapat berjalan semestinya. Pengelolaan data yang sudah terkomputerisasi memudahkan pihak bus dalam mencari data yang diperlukan sesuai dengan informasi dari pemesan tiket. Saat ini operasional kerja bus memiliki cukup banyak kendala seperti penginputan data yang tidak efektif dan efisien, tidak bisa cepat dalam pencarian data, tidak bisa cepat dalam pemberian informasi kepada calon pembeli tiket bus dan penyimpanan laporan data-data pemesanan tiket tidak terorganisir dengan baik. Hal ini dikarenakan masih adanya proses manual dalam pengolahan data operasional bus sampai pada pembuatan laporan.

Oleh karena itu, pada penelitian ini dikembangkan suatu konsep sistem pemesanan tiket yang berbasis dekstop yang bisa digunakan sebagai alat bantu untuk memudahkan pemrosesan data di Joglosemar Executive Shuttle Bus Semarang.

\section{Profil Perusahaan Joglosemar Executive Shuttle Bus}

Joglosemar Excutive Shuttle Bus adalah sebuah perusahaan yang bergerak di bidang pelayanan transportasi bus shuttle antar kota dengan pola antar dan jemput di agen-agen resmi Joglosemar. Joglosemar menggunakan armada bus Mercedes OF dan Isuzu ELF dengan fasilitas-fasilitas unggul seperti snack dan audio video dan Joglosemar menjadi sebuah pilihan yang sangat menarik bagi para pengguna.

Joglosemar dapat memenuhi pelayanan kepada masyarakat, salah satu pelayanan yang 
diberikan Joglosemar yaitu penumpang dapat memesan tiket sebelum tanggal keberangkatan dengan memilih kursi dan jadwal yang diinginkan. Hal ini bertujuan untuk memberikan pelayanan yang sebaik mungkin sehingga penumpang yang menggunakan jasa Joglosemar merasa senang dan senantiasa menggunakan jasa mereka dalam bidang transportasi.

\subsection{Prosedur Pemesanan Tiket}

Prosedur yang harus dilakukan oleh seorang pemesan yang akan memesan tiket adalah sebagai berikut:

1. Pemesan melakukan pemesanan tiket pada bagian pemesanan tiket (administrasi).

2. Pemesan harus memberi info tentang tanggal keberangkatan, tujuan keberangkatan, jam keberangkatan, nomor kursi, nama, telepon dan alamat.

3. Kemudian petugas administrasi akan mengecek apakah tiket yang dipesan untuk tujuan tersebut masih tersedia atau tidak.

4. Setelah mengetahui tiket masih tersedia maka petugas administrasi akan memasukkan data pemesan tiket sesuai dengan info dari pemesan tiket.

5. Setelah itu maka akan dilakukan perhitungan biaya yang harus dibayar dan pemesan harus membayar biaya yang tertera pada tiket dan kemudian pemesan akan mendapatkan tiket yang dipesan.

\subsection{Aturan Pemesanan Tiket}

Aturan yang harus diketahui oleh seorang pemesan yang akan memesan tiket adalah sebagai berikut:

1. Setiap keberangkatan, calon penumpang wajib menunggu di agen tempat pembelian tiket 30 menit sebelum jadwal keberangkatan.

2. Pembatalan tiket satu hari sebelum keberangkatan dapat dilakukan dengan syarat pengembalian uang tiket hanya sebesar $50 \%$.

3. Pembatalan tiket 2 jam sebelum keberangkatan dapat dilakukan dengan syarat tiket hangus dan uang tidak dapat kembali

4. Dalam perubahan jadwal keberangkatan minimal dapat dilakukan satu hari sebelum jadwal keberangkatan namun disaat perubahan jadwal keberangkatan ternyata tidak tersedia kursi untuk jam dan hari yang diminta, petugas administrasi mencoba menawarkan untuk jam atau hari yang lain.
Apabila pemesan merasa keberatan dengan jadwal yang ditawarkan, maka pemesan dapat melakukan pembatalan tiket dengan ketentuan pembatalan tiket seperti yang dijelaskan diatas.

\section{Analisis Sistem \\ 3.1 Analisis Masalah}

Permasalahan yang ada di Joglosemar adalah petugas kesulitan untuk mengolah data pemesanan tiket karena selama ini pengolahan data pemesanan tiket masih dalam bentuk manual atau belum terkomputerisasi sehingga pengolahan data kurang efektif dan efisien, padahal di era globalisasi komputer sudah merupakan kebutuhan dan merupakan suatu tuntutan. Berdasarkan hasil wawancara dengan petugas pemesanan tiket dapat didefinisikan masalah-masalah yang ada pada Joglosemar, antara lain:

1. Belum terkomputerisasi untuk bagian pemesanan tiket sehingga mempersulit dalam pengelolaan basis data yang meliputi pemasukan data, pengubahan data, penghapusan data dan pencarian data.

2. Sulitnya penyajian informasi secara cepat dan fleksibel karena penyajiannya / pengolahan datanya masih dalam bentuk manual.

3. Pencarian data yang kurang efektif dan efisien. Misalnya pencarian data pemesan tiket berdasarkan nama, tanggal berangkat atau kode pemesanan.

4. Belum tersedianya fasilitas untuk pembuatan laporan dari data dengan kriteria tertentu yang diinginkan. Misalnya pembuatan laporan pemesanan, keuangan dan pembatalan per trayek berdasarkan tanggal, bulan maupun tahun.

\subsection{Pemodelan Analisis Sistem}

Pada pemodelan analisis sistem ini menggunakan data contex diagram, data flow diagram, dan entity relationship diagram $[2,3]$.

\subsubsection{Data Contex Diagram}

Diagram konteks merupakan gambaran secara global terhadap proses yang terjadi dalam perangkat lunak [3]. Data Contex Diagram di sini menjelaskan tentang aplikasi sistem pemesanan tiket yang mendapatkan aliran data berupa data pemesanan tiket yang diperoleh dari 
pemesan. Berikut diagram konteks untuk sistem pemesanan tiket di Joglosemar.

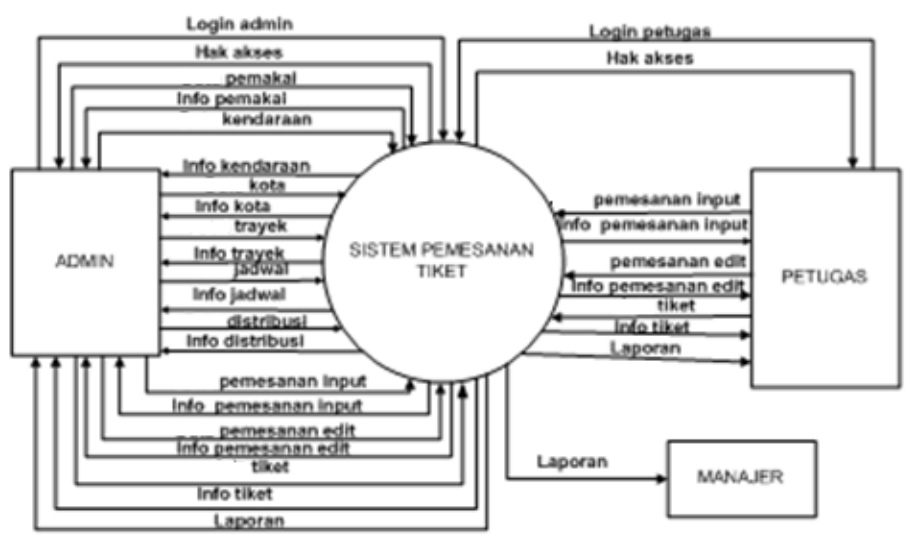

Gambar 1. DCD atau DFD Level 0 Sistem Pemesanan Tiket

\subsubsection{DFD level 1}

Pada DFD level 1 terdapat 11 proses di dalamnya, yaitu Login, pengelolaan data pemakai, pengelolaan data kendaraan, pengelolaan data pengemudi, pengelolaan data kota, pengelolaan data trayek, pengelolaan data jadwal, pegelolaan data distribusi, data pemesanan input, data pemesanan edit, pengelolaan tiket dan pelaporan. Gambar Data flow diagram level 1 dapat dilihat pada gambar 2.

Proses yang terdapat pada DFD Level 1 ada 12 proses antara lain :

1. Login

Proses login dimana admin maupun petugas terlebih dahulu memasukkan userID dan password untuk dapat masuk ke sistem pemesanan tiket pada Joglosemar Executive Shuttle Bus Semarang. Petugas administrasi berperan sebagai petugas dan pimpinan bagian administrasi berperan sebagai admin.

2. Pengelolaan data pemakai

Proses dimana admin dapat melihat, menambah, mengubah dan menghapus data pemakai yang berupa userID, password dan tingkatan.

3. Pengelolaan data kendaraan

Proses dimana admin dapat melihat, menambah, mengubah dan menghapus data kendaraan yang berupa nomor polisi kendaraan dan tipe kendaraan. Tipe kendaraan pada Joglosemar dibagi menjadi dua yaitu travel dan mini bus.
4. Pengelolaan data pengemudi

Proses dimana admin dapat melihat, menambah, mengubah dan menghapus data pengemudi yang berupa kode pengemudi dan nama pengemudi.

5. Pengelolaan data kota

Proses dimana admin dapat melihat, menambah, mengubah dan menghapus data kota yang berupa kode kota dan nama kota.

6. Pengelolaan data trayek

Proses dimana admin dapat melihat, menambah, mengubah dan menghapus data trayek yang berupa kode trayek, kode kota, asal kota, tujuan kota dan biaya perjalanan.

7. Pengelolaan data jadwal

Proses dimana admin dapat melihat, menambah, mengubah dan menghapus data jadwal yang berupa kode jadwal, kode trayek dan jam keberangkatan.

8. Pengelolaan data distribusi

Proses dimana admin dapat melihat, menambah, mengubah dan menghapus data distribusi. Data distribusi adalah penggabungan antara tabel trayek, tabel jadwal dan tabel kota yang akan digunakan dalam penampilan menu untuk memilih jadwal yang di inginkan

9. Data pemesanan input

Proses dimana admin maupun petugas dapat menambah, mengubah, menghapus dan memasukkan biaya perjalanan.

10.Data pemesanan edit 
Proses dimana admin maupun petugas dapat mencari, mengubah, menyimpan, menghapus dan memasukkan biaya perjalanan.

11.Pengelolaan tiket

Proses dimana admin maupun petugas dapat memasukkan data pemesan tiket dan dapat mencetak tiket.

\section{Pelaporan}

Proses dimana admin maupun petugas dapat melihat dan mencetak informasi laporan pemesanan, keuangan dan pembatalan per trayek berdasarkan tanggal, bulan maupun tahun.

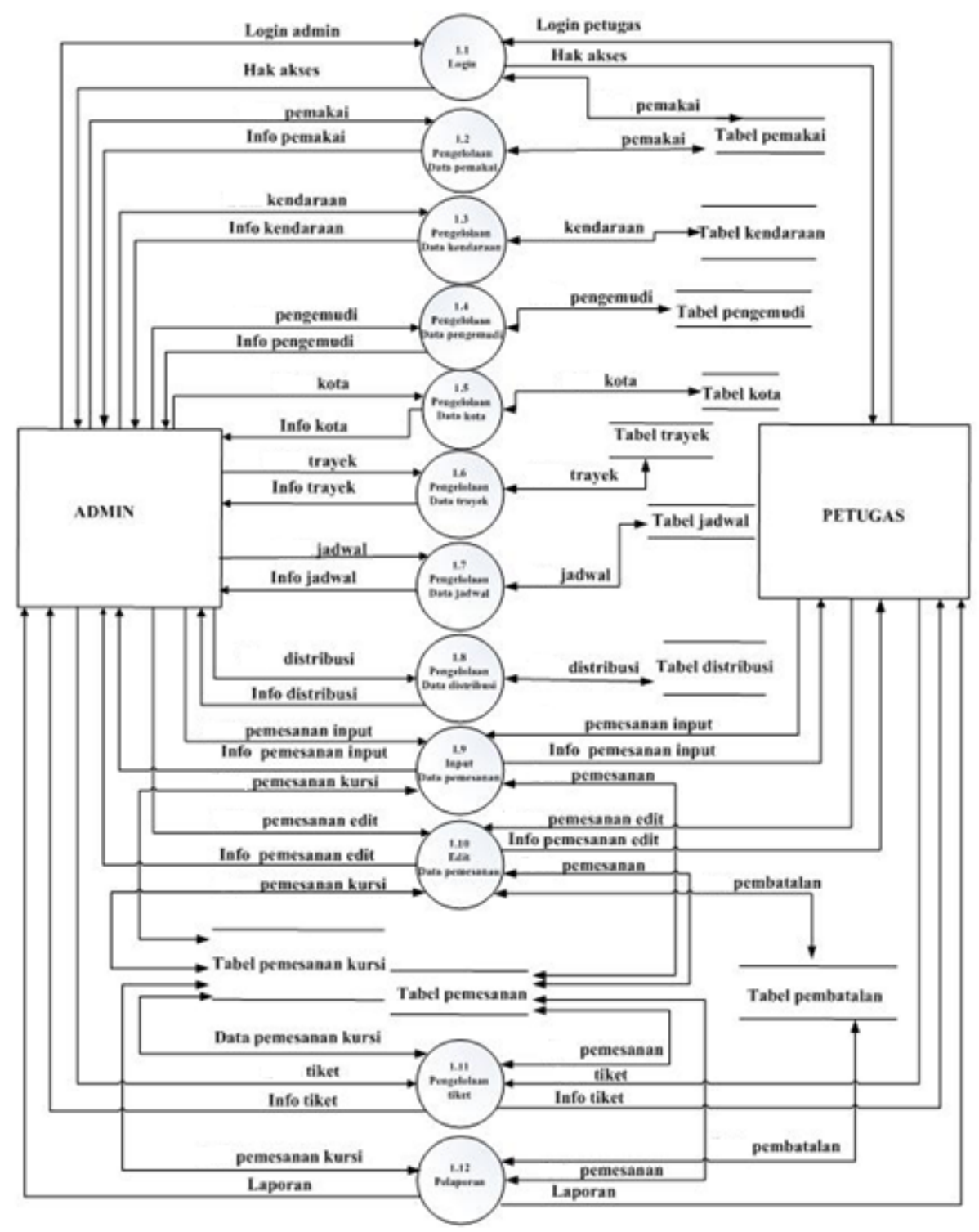

Gambar 2. DFD Level 1 Sistem Pemesanan Tiket

\subsubsection{Entity Relationship Diagram (ERD)}

ERD ini menjelaskan tentang himpunan entitas dan hubungan yang terjadi dalam system
[3,4]. Terdapat 9 himpunan entitas di dalam aplikasi sistem ini, yaitu pemakai, pemesanan, pemesanan kursi, kendaraan, pengemudi, trayek, 
pembatalan, distribusi dan jadwal. Himpunan entitas pemakai memiliki atribut userID, password, dan tingkat. Himpunan entitas pemesanan memiliki atribut kd_pemesanan, tanggal, status dan bayar. Himpunan entitas pemesanan kursi terdapat atribut kd_pemesanan_kursi, no_kursi, nama, telepon, dan alamat. Himpunan entitas kendaraan memiliki atribut no_pol dan tipe. Himpunan entitas pengemudi memiliki atribut kd_pengemudi dan nama pengemudi. Himpunan entitas trayek memiliki atribut kd_trayek, asal, tujuan dan biaya. Himpunan entitas pembatalan memiliki atribut kd_pembatalan dan denda. Himpunan entitas distribusi memiliki atribut kd_distribusi serta pada himpunan entitas jadwal memiliki atribut kd_jadwal dan jam. Ketujuh himpunan entitas ini memiliki hubungan satu sama lain seperti yang terdapat pada gambar 3 .

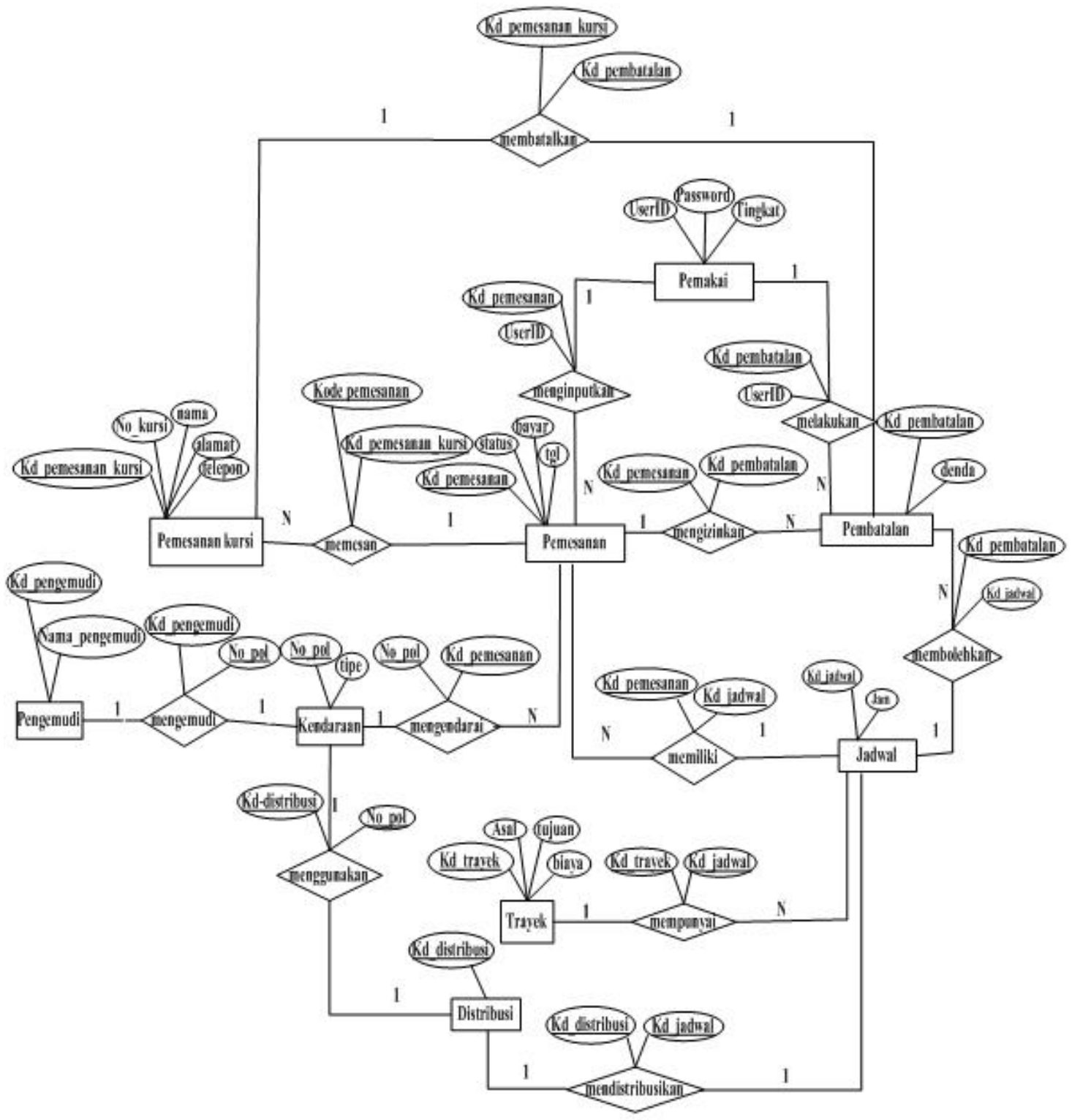

Gambar 3. ERD Sistem Pemesanan Tiket 


\section{Perancangan Sistem}

Dalam perancangan sistem akan dijelaskan mengenai perancangan fungsi, perancangan data dan perancangan antarmuka perangkat lunak [2].

\subsection{Perancangan Fungsi}

Fungsi yang dirancang dari sistem berjumlah

12 dengan rincian sebagai berikut.

1. Perancangan Fungsi Login

Deskripsi : Login yang dilakukan admin atau petugas sebelum masuk ke menu utama.

2. Perancangan Fungsi Menambah, Mengubah, dan Menghapus Data Pemakai

Deskripsi : Admin menambahkan data pemakai, mengubah data pemakai dan dapat menghapus data pemakai.

3. Perancangan Fungsi Menambah, Mengubah, dan Menghapus Data Kendaraan

Deskripsi : Admin menambahkan data kendaraan, mengubah data

4. Perancangan Fungsi Menambah, Mengubah, dan Menghapus Data Pengemudi

Deskripsi : Admin menambahkan data pengemudi, mengubah data pengemudi dan dapat menghapus data pengemudi.

5. Perancangan Fungsi Menambah, Mengubah, dan Menghapus Data Kota

Deskripsi : Admin menambahkan data kota, mengubah datakota dan dapat menghapus data kota.

6. Perancangan Fungsi Menambah, Mengubah, dan Menghapus Data Trayek

Deskripsi : Admin menambahkan data trayek, mengubah data trayek dan dapat menghapus data trayek.

7. Perancangan Fungsi Menambah, Mengubah, dan Menghapus Data Jadwal

Deskripsi : Admin menambahkan data jadwal, mengubah data jadwal dan dapat menghapus data jadwal.

8. Perancangan Fungsi Menambah, Mengubah, dan Menghapus Data Distribusi
Deskripsi : Admin menambahkan data distribusi, mengubah datadistribusi dan dapat menghapus data distribusi.

9. Perancangan Fungsi Menambah Data Pemesanan

Deskripsi : Admin atau petugas menambahkan data pemesanan.

10.Perancangan Fungsi Mengubah dan Menghapus Data Pemesanan

Deskripsi : Admin atau petugas mengubah dan menghapus data pemesanan.

11.Perancangan Fungsi Menampilkan dan Mencetak Tiket

Deskripsi : Admin atau petugas telah memasukkan data pemesan tiket sehingga dapat melihat tiket dan mencetak tiket

12.Perancangan Fungsi Menampilan dan Mencetak Laporan

Deskripsi : Admin atau petugas telah memasukkan data pemesan tiket sehingga dapat melihat laporan dan mencetak laporan.

\subsection{Perancangan Data}

Physical Data Model dari sistem pemesanan tiket dapat dilihat pada gambar 4.

\subsection{Perancangan Antarmuka}

Perancangan antarmuka atau desain interface merupakan bagian dari sistem yang digunakan untuk komunikasi antara user dengan system [2]. Rancangan antarmuka pada sistem ini meliputi rancangan antarmuka login, antarmuka menu utama untuk admin, antarmuka menu utama untuk petugas, antarmuka form data pemakai, antarmuka form data kendaraan, antarmuka form data pengemudi, antarmuka form data kota, antarmuka form data trayek, antarmuka form data jadwal, antarmuka form data distribusi, antarmuka form data pemesanan, antarmuka form edit data pemesanan, antarmuka form pencetakan tiket, antarmuka form laporan. Berikut adalah beberapa rancangan yang telah dibuat. 


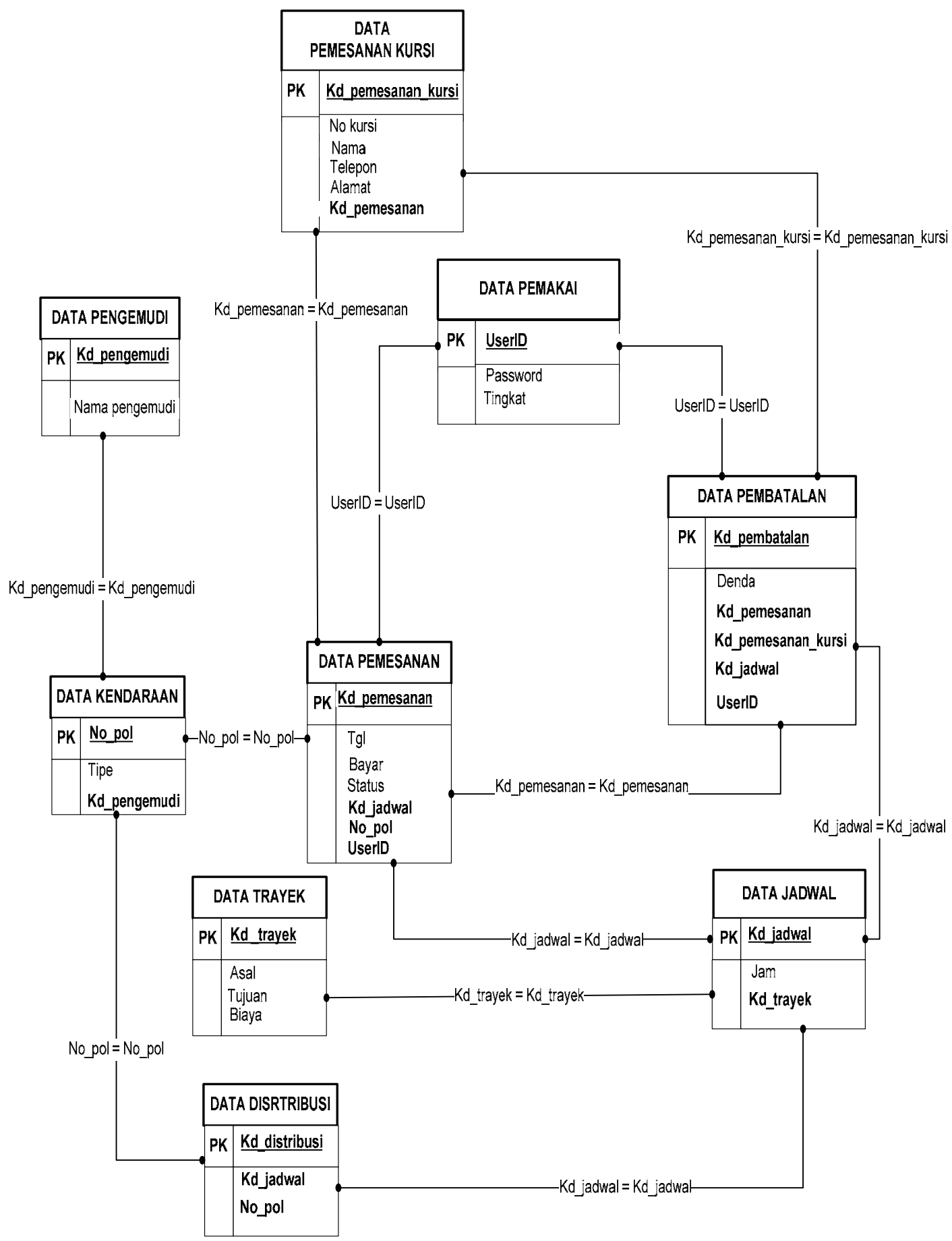

Gambar 4. Physical Data Model Sistem Pemesanan Tiket 


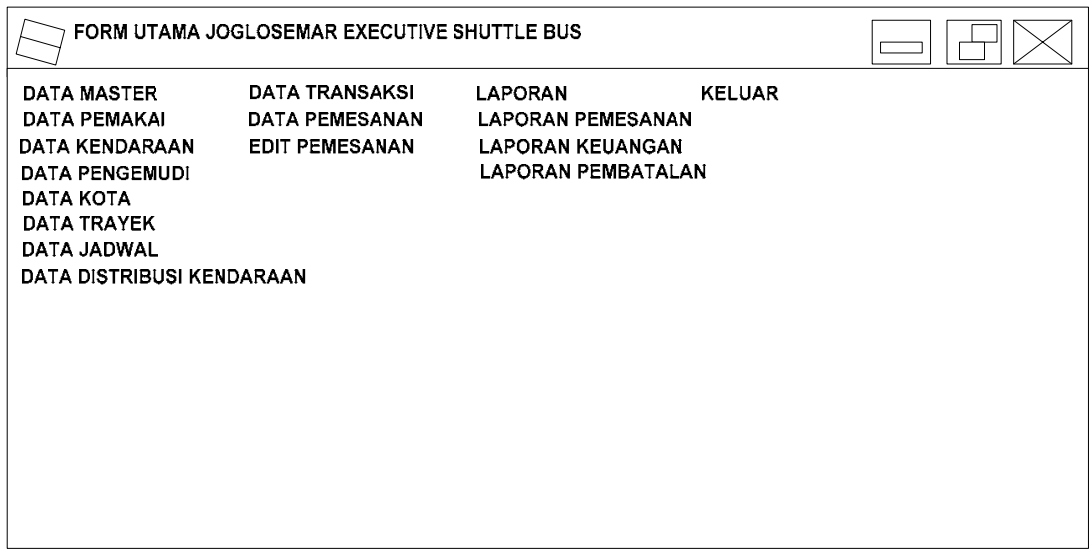

Gambar 5. Desain Menu Utama Untuk Admin

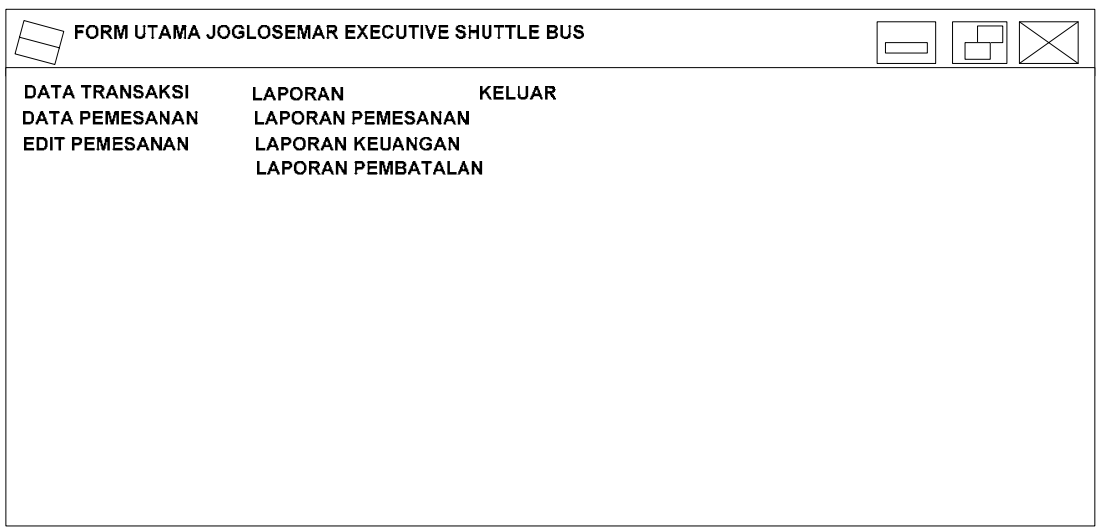

Gambar 6. Desain Menu Utama Untuk Petugas

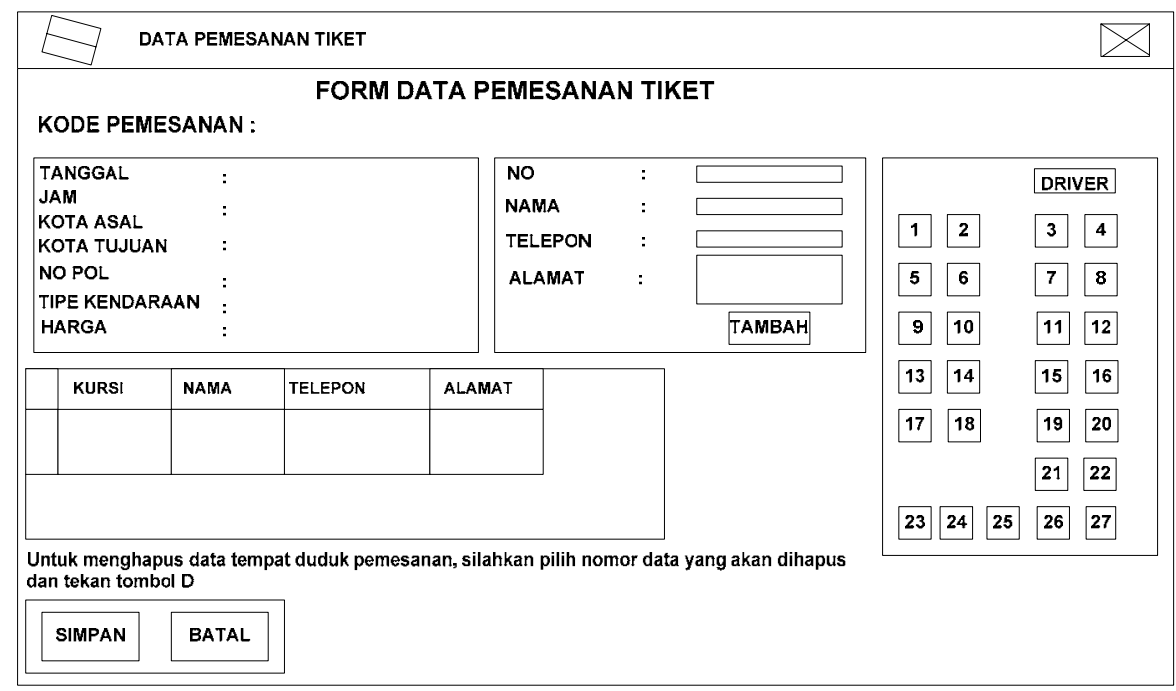

Gambar 7. Desain Form Tambah Data pemesanan 


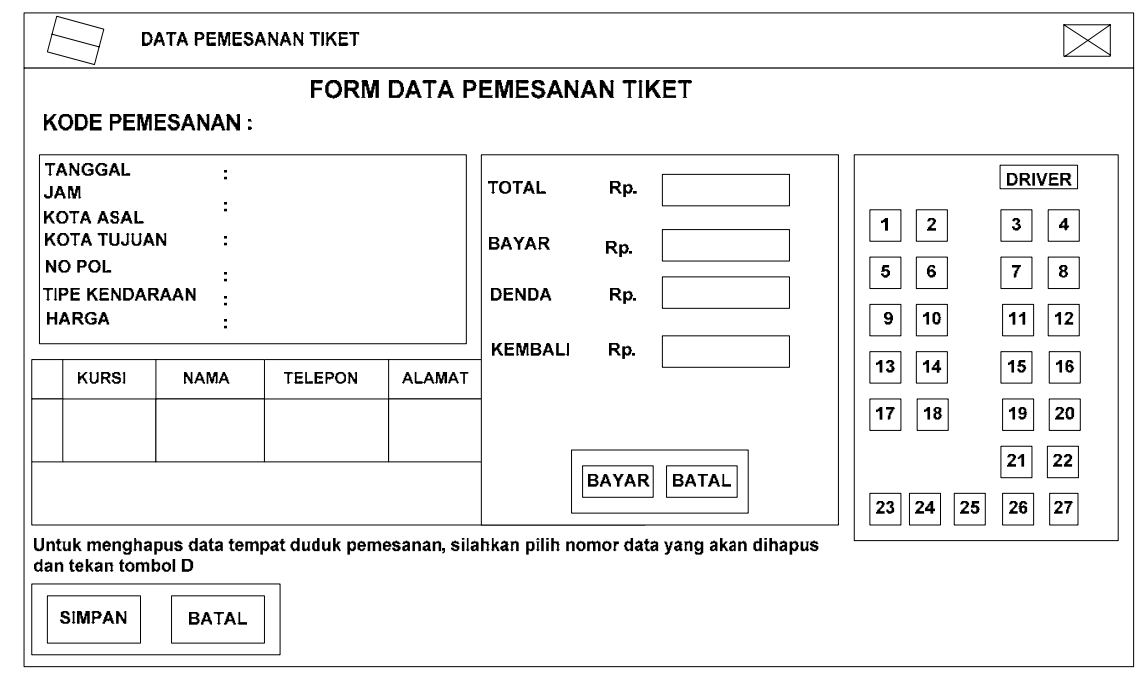

Gambar 8. Desain Form Memasukkan Biaya Perjalanan

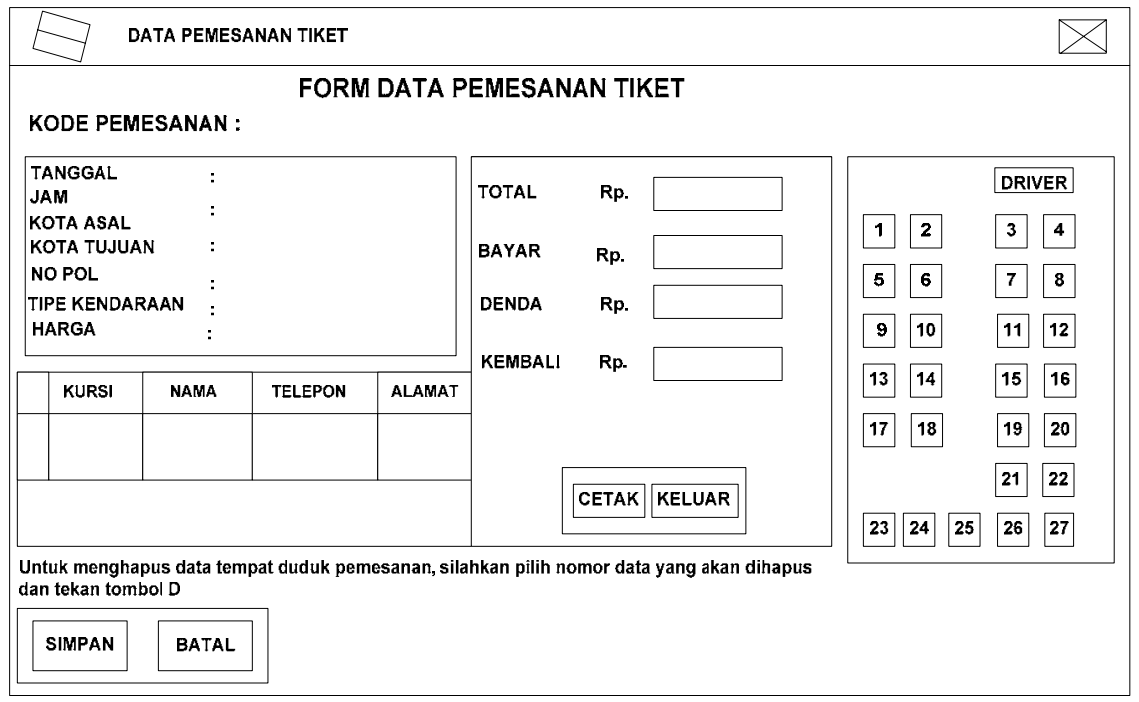

Gambar 9. Desain Form Pencetakan Tiket

\begin{tabular}{|c|c|c|c|c|c|c|c|c|}
\hline \multirow[b]{2}{*}{ Tanggal } & \multicolumn{8}{|c|}{$\begin{array}{l}\text { LAPORAN DATA PEMESANAN } \\
\text { TANGGAL 02/02/2011 s/d 05/02/2011 } \\
\text { Trayek Semarang - Jogja }\end{array}$} \\
\hline & Tipe Kendaraan & No Pol & Pengemudi Jam & Asal & Tujuan & $\begin{array}{c}\text { Jumlah } \\
\text { kursi }\end{array}$ & Bayar & Petugas \\
\hline & & & Nama & & Kursi & & & \\
\hline JUMLAH & & & & & & & & \\
\hline
\end{tabular}

Gambar 10. Desain Cetak Laporan Pemesanan 


\begin{tabular}{|c|c|c|c|c|}
\hline & $\begin{array}{l}\text { LOGO } \\
\text { JOGLOSEMAR }\end{array}$ & $\begin{array}{l}\text { PEMESANAN } \\
\text { JOGLOSEMAR E } \\
\text { SHUTTLE }\end{array}$ & $\begin{array}{l}\text { N TIKET } \\
\text { EXECUTIVE } \\
\text { BUS }\end{array}$ & \\
\hline & $\begin{array}{l}\text { Aturan Pemesanan Tiket } \\
\text { Calon penumpang wajib menunggu di agen tempat pembelian tiket } \\
30 \text { menit sebelum jadwal keberangkatan. } \\
\text { Pembatalan tiket satu hari sebelum keberangkatan dapat dilakukan } \\
\text { dnegan syarat pengembalian uang tiket hanya sebesar } 5 \% \% \text {. } \\
\text { Pembatalan tiket } 2 \text { jam sebelum keberangkatan dapat dilakukan } \\
\text { dengan syarat tiket hangus dan uang tidak dapat kembali } \\
\text { Dalam perubahan jadwal keberangkatan minimal dapat dilakukan } \\
\text { satu hari sebelum jadwal keberangkatan namun disaat perubahan } \\
\text { jadwal keberangkatan ternyata tidak tersedia kursi untuk jam } \\
\text { dan hari yang dimintan petugas administrasi mencoba menawarkan untuk } \\
\text { jam atau hari yang lain. Apabila pemesan merasa keberatan dengan } \\
\text { jadwal yang ditawarkan, maka pemesan dapat melakukan pembatalan } \\
\text { tiket dengan ketentuan pembatalan tiket seperti yang dijelaskan } \\
\text { diatas. }\end{array}$ & $\begin{array}{l}\text { Kode Pemesanan } \\
\text { Nama } \\
\text { Alamat } \\
\text { Tanggal } \\
\text { Asal } \\
\text { Tujuan } \\
\text { Jam } \\
\text { Tipe Kendaraan } \\
\text { No Pol Kendaraan } \\
\text { Harga Tiket }\end{array}$ & $\begin{array}{l}\text { JL. Setia Budi, Srondol } \\
\text { JL Slamet Riyadi No, } 361 \\
\text { Jl. Magelang Km 5,6 } \\
\text { JL. Jend Sudirman Kompl. Ruko Palma No. } 6\end{array}$ & No Kursi \\
\hline
\end{tabular}

Gambar 11. Desain Tiket

\section{Implementasi}

Rancangan system yang dibuat kemudian diimplementasikan dengan menggunakan Microsoft Visual Basic 6.0 dan Microsoft
Access 2007 untuk media penyimpanan data $[5,6]$. Berikut beberapa tampilan hasil implementasi.

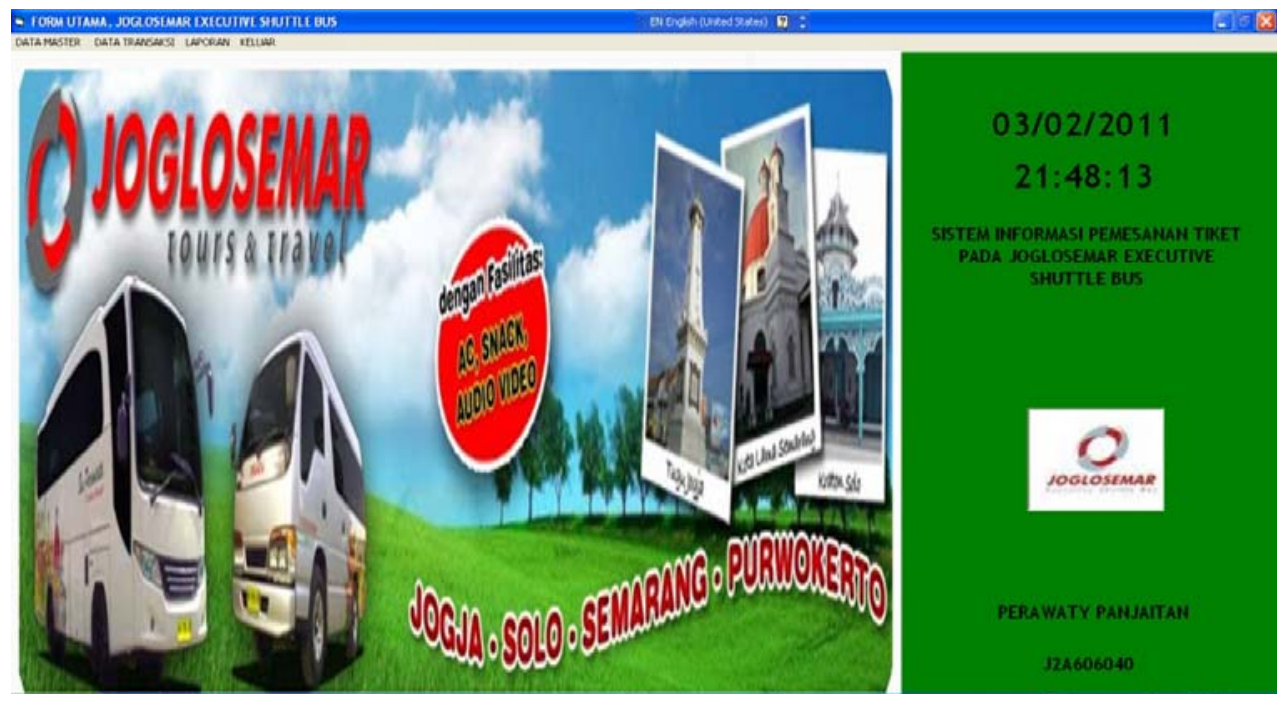

Gambar 12. Halaman Menu Utama Untuk Admin 


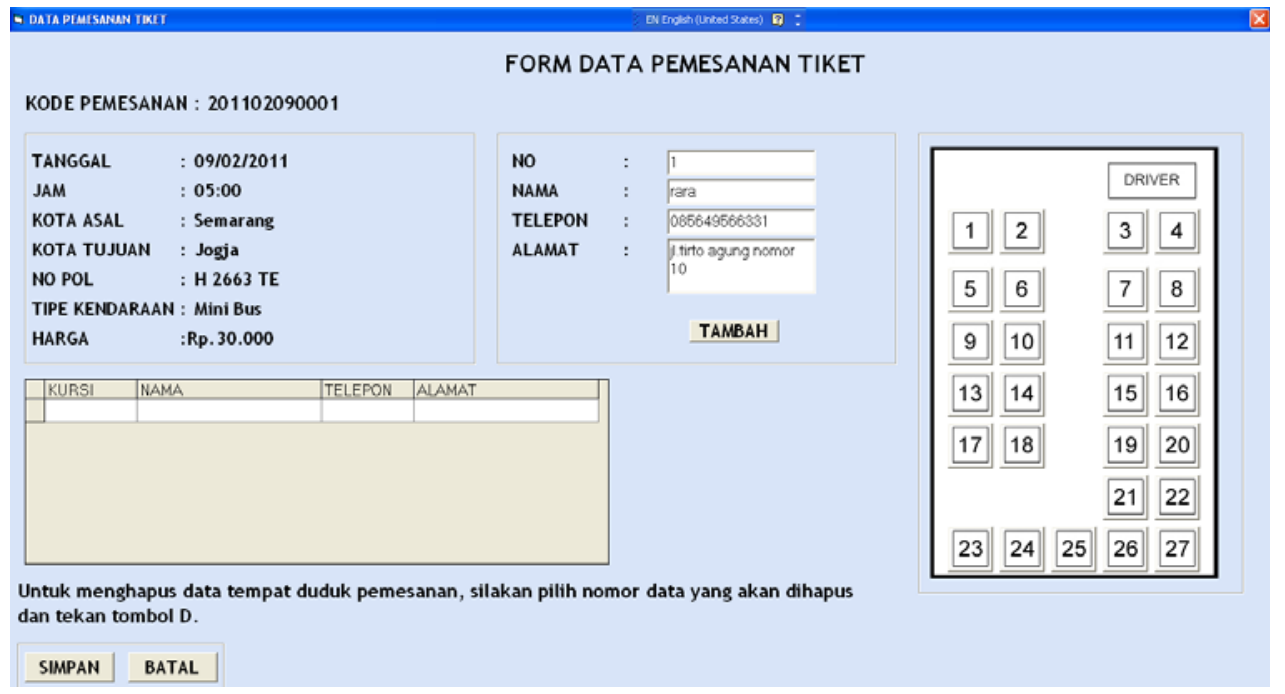

Gambar 13. Tampilan Form Data Pemesanan Tiket

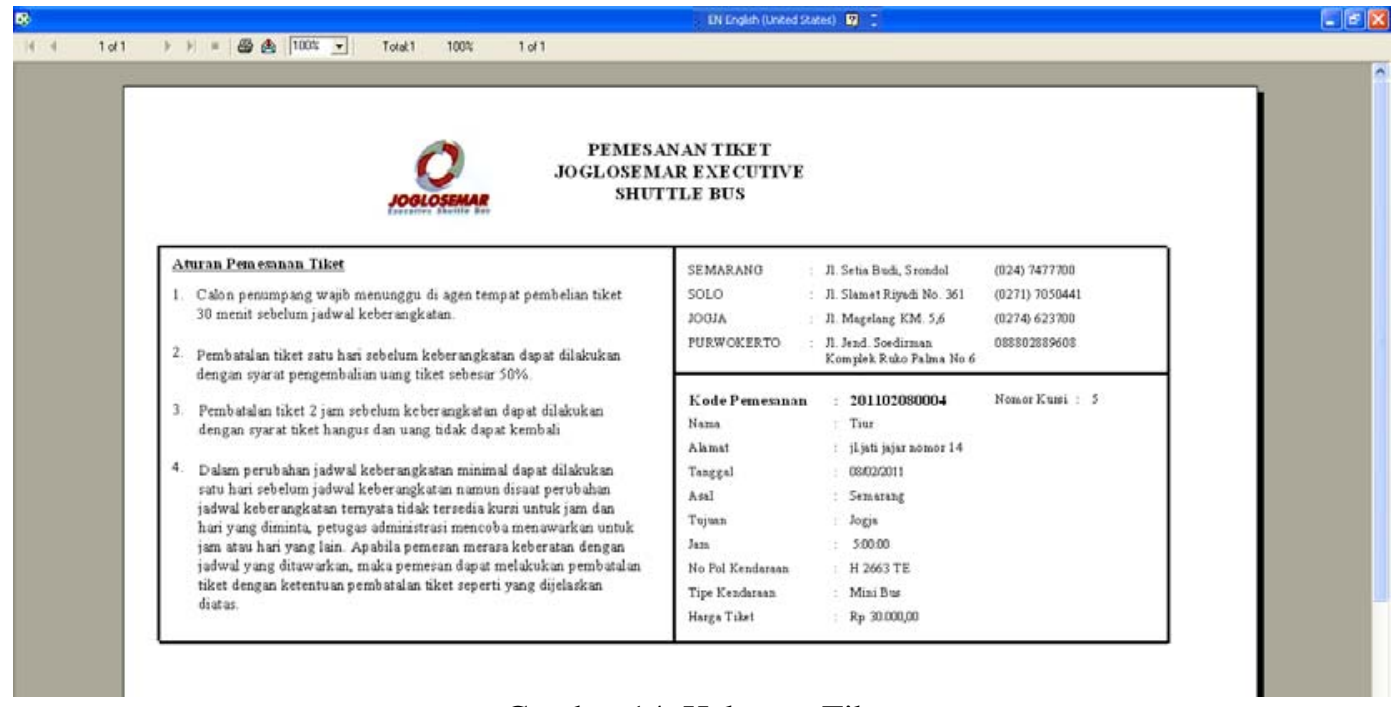

Gambar 14. Halaman Tiket

\section{Kesimpulan dan Saran}

\subsection{Kesimpulan}

Kesimpulan dalam penelitian ini adalah menghasilkan sistem pemesanan tiket pada Joglosemar Executive Shuttle Bus Semarang berbasis dekstop yang dapat digunakan untuk meningkatkan kinerja petugas dalam penginputan data, pencarian data sesuai informasi yang diperlukan, memberikan informasi yang cepat kepada calon pembeli tiket dan penyimpanan laporan data-data pemesanan tiket. Sistem ini dapat dijadikan alternatif bagi petugas administrasi pemesanan tiket pada Joglosemar Executive Shuttle Bus Semarang sehingga dapat mengurangi kemungkinan kesalahan data dalam mengolah data pemesanan tiket.

\subsection{Saran}

Perancangan program aplikasi pemesanan tiket pada Joglosemar Executive Shuttle Bus Semarang ini masih berbasis desktop sehingga 
saran untuk program aplikasi pemesanan tiket adalah sistem pemesanan tiket pada Joglosemar Executive Shuttle Bus Semarang diharapkan dapat berbasis web, sehingga memudahkan masyarakat dalam memesan tiket lewat internet tanpa harus ke agen Joglosemar Executive Shuttle Bus Semarang secara langsung.

\section{Referensi}

[1]. Suryana, Djohan. 2010. Infrastruktur Transportasi Darat. http://ekonomi.kompasiana.com/2010/01/29/ infrastruktur-transportasi-darat/ Tanggal akses 4 Mei 2010, Pukul 12.30 WIB.
[2]. Pressman, Roger S. 1997. Rekayasa Perangkat Lunak. Andi. Yogyakarta.

[3]. Ponco, S.W. 1999. Analisa Perancangan Sistem. Fajar. Jakarta.

[4]. Fathansyah, 2004. Basis Data. Informatika. Bandung.

[5]. Madcoms, 2005. Mahir dalam 7 hari Pemrograman Visual Basic 6.0. Andi. Madiun.

[6]. Yuswanto, 2003. Pemrograman Dasar Microsoft Visual Basic 6.0. Stikom. Surabaya. 